\title{
Effect of Economic Evaluation of Oryza sativa under different Planting Methods and Nutrient Management Practices
}

\author{
C. Mohanasundar*, M. Saravana Perumal and G. Murugan \\ Department of Agronomy, Faculty of Agriculture, Annamalai University, \\ Chidambaram - 608002, Tamil Nadu state, India \\ *Corresponding author
}

Keywords

Planting methods, Soil health, Crop management, Environment

Article Info

\section{Accepted:}

15 January 2021

Available Online:

10 February 2021

\section{A B S T R A C T}

A field experiment was conducted at Annamalai University Experimental Farm, Annamalainagar, during Samba season 2017 (August-November) to evaluate different methods of rice cultivation along with certain levels of nutrients and sources, on its growth, yield parameter and economics of rice. The experiment was laid out in Split Plot Design. The planting methods was assigned to main plots while, different levels and sources of nutrients to the sub plots. Two planting methods viz., $\left(\mathrm{M}_{1}\right)$ wet seeded method and $\left(\mathrm{M}_{2}\right)$ transplanting method were tried. The sub treatments were, Control (No manure) $\left(\mathrm{S}_{1}\right)$, Recommended dose of fertilizer (120:38:38 N, P and $\left.\mathrm{K} \mathrm{kg} \mathrm{ha}^{-1}\right)\left(\mathrm{S}_{2}\right)$, RDF (120:38:38 N, P and K kg ha $\left.{ }^{-1}\right)$ + Pressmud (5 tonnsha $\left.{ }^{-1}\right)+$ zinc sulphate $\left(25 \mathrm{~kg} \mathrm{ha}^{-1}\right)\left(\mathrm{S}_{3}\right)$, RDF (120:38:38 N, P and $\left.\mathrm{K} \mathrm{kg} \mathrm{ha}^{-1}\right)+$ Azospirillum bracilance @ $2 \mathrm{~kg} \mathrm{ha}^{-1}$ as a soil application + zinc sulphate $\left(25 \mathrm{~kg} \mathrm{ha}^{-1}\right)\left(\mathrm{S}_{4}\right)$, RDF (120:38:38 N, P and $\left.\mathrm{K} \mathrm{kg} \mathrm{ha}^{-1}\right)+$ pressmud (5 tonnsha $\left.{ }^{-1}\right)+$ Azospirillum bracilance @ $2 \mathrm{~kg} \mathrm{ha}^{-1}$ as a soil application + zinc sulphate $\left(25 \mathrm{~kg} \mathrm{ha}^{-1}\right)\left(\mathrm{S}_{5}\right)$. The results of the study revealed that, among the main plot treatments, i.e., various levels of crop establishments, transplanting method recorded significantly highest grain $4421 \mathrm{~kg} \mathrm{ha}^{-1}$ and straw yield $5058 \mathrm{~kg} \mathrm{ha}^{-1}$ rate than compare to direct seeded method of planting. Among different sources and levels, i.e., five sub plot treatments, large variation were noticed RDF (120:38:38 $\mathrm{N}, \mathrm{P}$ and $\left.\mathrm{K} \mathrm{kg} \mathrm{ha}^{-1}\right)+$ pressmud $\left(5\right.$ tonnsha $\left.^{-1}\right)+$ Azospirillum bracilance @ $2 \mathrm{~kg}$ $\mathrm{ha}^{-1}$ as a soil application + zinc sulphate $\left(25 \mathrm{~kg} \mathrm{ha}^{-1}\right)\left(\mathrm{S}_{5}\right)$ recorded highest grain $5244 \mathrm{~kg} \mathrm{ha}^{-1}$ and straw yield $5927 \mathrm{~kg} \mathrm{ha}^{-1}$ compared to the rest of the treatments, yet, it was found on par with $\left(\mathrm{S}_{3}\right)$. Gross monetary returns (Rs. 82868), net monetary returns (Rs. 50173) and B:C ratio (Rs. 2.53) were recorded significantly higher in transplanting method compare to direct seeded method of planting. Among different sources and levels, i.e., five sub plot treatments, large variation were observed RDF $\left(120: 38: 38 \mathrm{~N}, \mathrm{P}\right.$ and $\left.\mathrm{K} \mathrm{kg} \mathrm{ha}^{-1}\right)+$ pressmud $\left(5\right.$ tonnsha $\left.^{-1}\right)+$ Azospirillum bracilance@ $2 \mathrm{~kg} \mathrm{ha}^{-1}$ as a soil application + zinc sulphate $(25 \mathrm{~kg}$ $\left.\mathrm{ha}^{-1}\right)\left(\mathrm{S}_{5}\right)$ was better for realizing higher grain yield, straw yield and economic returns apart from sustainable better soil nutrient status. 


\section{Introduction}

Rice (Oryza sativa) is the most vital food crop and a major food grain for more than one third of the world's population (Zhao et al., 2011). Global demand for food is rising because of population growth, increasing affluence and changing dietary habits.

The UN/FAO forecasts that global food production will need to increase by over 40 per cent by 2030 and 70 per cent by 2050 (FAO, 2009).

Direct seeding of rice is the process of establishing the crop from seeds sown in the field rather than by transplanting seeding from the nursery. Direct seeding avoids three basic operations namely puddling (process of soil is compacted to reduce water seepage), transplanting and maintain standing water (Farooq et al., 2011).

It requires less labour and direct seeded plants mature 7 to 10 days earlier than transplanted rice. The other way of establishment is not by sowing seeds but by transplanting seedlings that are grown in nursery first. Transplanting requires less seeds but much more labour, and the crop takes longer to mature because of transplant shock. Manual transplanting of seedlings is very labour intensive. Planting in straight rows will make it easier to weed or apply fertilizers, herbicides, or insecticides.

The concept of integrated nutrient management through the judicious mixing of organic as well as inorganic sources of nutrients is an appropriate, which will not only economize the use of chemical fertilizers but also improve the physio-chemical status of the soil(Goud and Konde, 2009).

Under these circumstances, more emphasis is now being given on integration of inorganic and organics including crop residues, agro- based industrial wastes and by-products to improve the soil productivity.

Besides improving nutrient status of soil, it also helps in improving physical, chemical and biological properties of soil towards betterment of soil quality, and permeability which increases fertilizer use efficiency due to higher addition of humus (Mankotia et al., 2008).

Zinc deficiency is the wide spread micronutrient disorder in lowland rice and application of zinc along with nitrogenous fertilizers increased the grain yield dramatically in most cases (Chaudhary et al., 2007). Zinc deficiency in rice appears right from seedling stage in nursery and three weeks after transplanting in main field. Zinc deficiency is considered the most widespread disorder in lowland rice (Fageria et al., 2002).

\section{Materials and Methods}

A Field experiment was conducted in the Experimental Farm, Department of Agronomy, Faculty of Agriculture, Annamalai University, Annamalainagar to study the response of rice variety $\mathrm{CO} 47$ to varied levels of RDF (Recommended dose of fertilizer) with organic sources (Pressmud and Azospirillum bracilance) and inorganic sources (Recommended dose of fertilizers and Zinc sulphate) viz., wet seeded rice and transplanted rice. The study was conducted during 2017 (August - November).The experiment was laid out in Split Plot Design.

The planting methods was assigned to main plots while, different levels and sources of nutrients to the sub plots. Two planting methods viz., $\left(\mathrm{M}_{1}\right)$ wet seeded method and $\left(\mathrm{M}_{2}\right)$ transplanting method were tried. The sub treatments were, Control (No manure) $\left(\mathrm{S}_{1}\right)$, Recommended dose of fertilizer (120:38:38 N, $\mathrm{P}$ and $\left.\mathrm{K} \mathrm{kg} \mathrm{ha}^{-1}\right)\left(\mathrm{S}_{2}\right)$, RDF (120:38:38 N, P 
and $\left.\mathrm{K} \mathrm{kg} \mathrm{ha}^{-1}\right)+$ Pressmud (5 tonnsha $\left.{ }^{-1}\right)+$ zinc sulphate $\left(25 \mathrm{~kg} \mathrm{ha}^{-1}\right)\left(\mathrm{S}_{3}\right)$, RDF (120:38:38 N, $\mathrm{P}$ and $\left.\mathrm{K} \mathrm{kg} \mathrm{ha}{ }^{-1}\right)+$ Azospirillum bracilance@ $2 \mathrm{~kg} \mathrm{ha}^{-1}$ as a soil application + zinc sulphate $\left(25 \mathrm{~kg} \mathrm{ha}^{-1}\right)\left(\mathrm{S}_{4}\right)$, RDF (120:38:38 N, P and K $\left.\mathrm{kg} \mathrm{ha}{ }^{-1}\right)+$ pressmud $\left(5\right.$ tonnsha $\left.^{-1}\right)+$ Azospirillum bracilance@ $2 \mathrm{~kg} \mathrm{ha}^{-1}$ as a soil application + zinc sulphate $\left(25 \mathrm{~kg} \mathrm{ha}^{-1}\right)\left(\mathrm{S}_{5}\right)$.

Pressmud with $\mathrm{N}-0.12 \%, \mathrm{P}_{2} \mathrm{O}_{5}-2.41 \%$, $\mathrm{K}_{2} \mathrm{O}-0.64 \%$ @ tonnes $\mathrm{ha}^{-1}$ was applied in last puddling at basal as per the treatment schedule or two days before sowing or transplanting based on the treatments.

Azospirillum bracilance@ $2 \mathrm{~kg} / \mathrm{ha}$ as a soil application was applied at basal as per the treatment schedule two days last puddling before sowing or transplanting based on the treatments.

The fertilizers were applied to the experimental field as per the recommended manurial schedule of 120:38:38 kg N, $\mathrm{P}_{2} \mathrm{O}_{5}$ and $\mathrm{K}_{2} \mathrm{O} \mathrm{ha}^{-1}$. Urea (46\% N), Single super phosphate $\left(16 \% \mathrm{P}_{2} \mathrm{O}_{5}\right)$ and Muriate of potash $\left(60 \% \mathrm{~K}_{2} \mathrm{O}\right)$ fertilizers were used to supply $\mathrm{N}$, $\mathrm{P}$ and $\mathrm{K}$ nutrients, respectively.

Zinc sulphate@ $25 \mathrm{~kg} \mathrm{ha}^{-1}$ was applied in last puddling at basal as per the treatment schedule or two days before sowing or transplanting based on the treatments.

Biometric observations on plant height, number of tillers $\mathrm{m}^{-2}$, leaf area index (LAI),yield parameters were recorded at harvest. The data was subjected to statistical scrutiny to arrive at meaningful for the effect of treatments on rice crop.

\section{Biometric and yield observation}

Five sample per hills in each plot were peg marked randomly for recording biometric observation. The observations were recorded at different stages of crop growth as given blow.

\section{Plant height (cm)}

Plant height was recorded at tillering, flowering and at harvesting stage by measuring the height of the sample plant from the surface of the soil to the tip of the top leaf. The mean value of all the five sample hills was computed and expressed in $\mathrm{cm}$.

\section{Number of tillers $\mathbf{m}^{-2}$}

The number of tillers $\mathrm{m}^{-2}$ was recorded by counting the tillers at maximum tillering stage of the crop (35 - 40 DAT).

\section{Leaf area index (LAI)}

Leaf area was estimated at flowering stage (60 DAT) of the crop by using the following formula (Yoshida et al., 1976).

$\mathrm{LA}=\mathrm{L} \times \mathrm{W} \times \mathrm{K}$

Where,

$\mathrm{LA}=$ leaf area in $\mathrm{cm}^{2}$

$\mathrm{L}=$ length of leaf in $\mathrm{cm}\left(3^{\text {rd }}\right.$ leaf from top $)$

$\mathrm{W}=$ maximum width of leaf in $\mathrm{cm}\left(3^{\text {rd }}\right.$ leaf $)$

$\mathrm{K}=$ Adjustment factor $(0.75)$

The total leaf area of the mother tiller of sample hill was calculated and was multiplied by the number of tillers in each hill. The total area was arrived by multiplying the leaf area hill $^{-1}$ with number of hill $\mathrm{m}^{-2}$. The leaf area index was computed by using the formula given below.

$\mathrm{LAI}=\frac{\text { Total leaf area per unit area }\left(\mathrm{m}^{2}\right)}{\text { Unit land area }\left(\mathrm{m}^{2}\right)}$ 


\section{Yield}

\section{Grain yield}

The matured crop was harvested from the net plot area and the grains separated, cleaned and dried to 14 per cent moisture content. The total yield was computed and recorded inkg $\mathrm{ha}^{-1}$.

\section{Straw yield}

The straw yield obtained from each net plot area after threshing was sun dried and weighed and expressed in $\mathrm{kg} \mathrm{ha}^{-1}$.

\section{Economics}

The cost of cultivation for each treatment was worked out. Similarly, gross returns were calculated based on current market price of the produce. The net returns were obtained after deducting the cost of cultivation from gross returns. Later, the benefit-cost ratio was worked out by using the formula:

Return per rupee invested

$=\frac{\text { Gross return }\left(\text { Rs. } h a^{-1}\right)}{\text { Total cost of cultivation }\left(R s \cdot h a^{-1}\right)}$

\section{Statistical Analysis}

The data on various characters studied during the course of investigation were statistically analysed for split plot design. Wherever treatment differences were significant (" $F$ " test), critical differences were worked out at five per cent probability level. Treatment differences that were not significant were denoted as "NS".

\section{Results and Discussion}

The present investigation showed significant difference in main as well as sub treatments. All the growth components viz., plant height, number of tillers $\mathrm{m}^{-2}$, LAI, yield and economics showed superior performance with transplanting method, compared to wet seeded method of rice cultivation.

\section{Growth components}

\section{Plant height}

The data on plant height showed significant difference among main as well as sub treatments at all the stages of observation viz, flowering and harvesting stages are presented in Table 1.

Among the main treatments, wet seeded method gave the highest mean plant height of $77.4 \mathrm{~cm}$ followed by transplanting method with a plant height of $73.6 \mathrm{~cm}$ at flowering stages and transplanting method gave the highest mean plant height of $85.3 \mathrm{~cm}$ followed by wet seeded method with a plant height of $81.6 \mathrm{~cm}$ at harvesting stage respectively. The least plant height was recorded in flowering stage by transplanting method and harvesting stage by wet seeded method.

Regarding sub treatments, i.e., certain levels and sources of nutrients, RDF + pressmud + Azospirillumbracilance@ $2 \mathrm{~kg} \mathrm{ha}^{-1}$ as a soil application + zinc sulphate $\left(\mathrm{S}_{5}\right)$ recorded the highest plants height of 84.9 and $92.8 \mathrm{~cm}$ which was on par with RDF + Pressmud + zinc sulphate $\left(S_{3}\right)$ at flowering and harvesting stages respectively. The least plant height was obtained with no fertilizer plot $\left(\mathrm{S}_{1}\right)$, the plant height being $63.0 \mathrm{~cm}$ and $71.2 \mathrm{~cm}$ at flowering stage and harvesting stages respectively.

There was significant interaction between the planting methods and application of different nutrients on rice for plant height. The treatment combination of wed seeded method $+\mathrm{RDF}+$ pressmud + Azospirillum bracilance@ $2 \mathrm{~kg} \mathrm{ha}^{-1}$ as a soil application + zinc sulphate $\left(\mathrm{M}_{1} \mathrm{~S}_{5}\right)$ recorded the highest plant height of $87.6 \mathrm{~cm}$ at 
flowering stage of crop. The least plant height was recorded by the treatment transplant method + control (No manure) $\left(\mathrm{M}_{2} \mathrm{~S}_{1}\right)$.

The treatment combination of transplanting method + RDF + pressmud + Azospirillum bracilance@2 $\mathrm{kg} \mathrm{ha}^{-1}$ as a soil application + zinc sulphate $\left(\mathrm{M}_{2} \mathrm{~S}_{5}\right)$ recorded the highest plant height of $95.5 \mathrm{~cm}$ at harvesting stage of crop. The least plant height of $71.2 \mathrm{~cm}$ was recorded by the treatment wet seeded method + control (No manure) $\left(\mathrm{M}_{1} \mathrm{~S}_{1}\right)$.

This might be due to the fact that, younger seedlings in transplanting method had higher vigour, more root growth and transplantation shock occur during the initial growth stages after which stimulated plant height. Transplanting plants had more open architecture, with tillers spread wide more widely covering more ground area and more erect leaves that avoid mutual shading of leaves, resulted in optimum LAI due to significant increase in leaf size. The above results are in accordance with earlier findings of Ehsanullah et al., (2000).

\section{Number of tillers $\mathrm{m}^{-2}$}

The data on number of tillers $\mathrm{m}^{-2}$ are presented in Table 2. The main and sub treatments significantly influenced the tiller number transplanting method $\left(\mathrm{M}_{2}\right)$ produced the largest number of tillers with $443.2 \mathrm{~m}^{-2}$, followed by wet seeded method $\left(\mathrm{M}_{1}\right)$ with 408 tillers $\mathrm{m}^{-2}$.

Among various sub treatments tried, RDF + pressmud + Azospirillum bracilance@ 2 kg $\mathrm{ha}^{-1}$ as a soil application + zinc sulphate $\left(\mathrm{S}_{5}\right)$ recorded the highest tillers with $509 \mathrm{~m}^{-2}$ and $494 \mathrm{~m}^{-2}$ which was on par with RDF + Pressmud + zinc sulphate $\left(\mathrm{S}_{3}\right)$ respectively. Recommended dose of fertilizer (RDF) $\left(S_{2}\right)$ could produce 374.5 tillers $\mathrm{m}^{-2}$ which was significantly lower to rest of the treatments except Control $\left(S_{1}\right)$. There was significant interaction between the planting methods and application of different nutrients on rice for number of tillers $\mathrm{m}^{-2}$. The treatment combination of transplant method $+\mathrm{RDF}+$ pressmud + Azospirillum bracilance@ 2 kg $\mathrm{ha}^{-1}$ as a soil application + zinc sulphate $\left(\mathrm{M}_{2} \mathrm{~S}_{5}\right)$ recorded the highest tillers of $532 \mathrm{~m}^{-2}$ and least tillers was recorded by the treatment wet seeded method + control (No manure) $\left(\mathrm{M}_{1} \mathrm{~S}_{1}\right)$.

Improvement in growth components as a result of application of organic fertilizers might be due to the enhanced metabolic activities which lead to increase in various plant metabolites responsible for cell division and cell elongation (Hatwar et al., 2003). The increment in plant height may be brought about by the presence of boron (B) which acts as a constituent of cell walls and membranes (Krikby and Romheld, 2004).

\section{Leaf area Index (LAI)}

Noteworthy difference among main and sub treatments was observed on leaf area index at flowering stages are presented in Table 2 . Between certain main treatments, the largest LAI of 6.0 was obtained with transplanting method $\left(\mathrm{M}_{2}\right)$ which was significantly higher than that of the rest of the treatments. Wet seeded method $\left(\mathrm{M}_{1}\right)$ produced the least LAI of 5.6.

Within sub plot treatments, $\mathrm{RDF}+$ pressmud +Azospirillum bracilance@ $2 \mathrm{~kg} \mathrm{ha}^{-1}$ as a soil application + zinc sulphate $\left(\mathrm{S}_{5}\right)$ produced the largest LAI of 6.7 and was followed by on par with RDF + Pressmud + zinc sulphate $\left(\mathrm{S}_{3}\right)$ with 6.6. The least LAI (4.6) was with control $\left(\mathrm{S}_{1}\right)$.

There was significant interaction between the planting methods and application different nutrients on rice for leaf area index. The 
treatment combination of transplanting method + RDF + pressmud + Azospirillum bracilance@2 $\mathrm{kg} \mathrm{ha}^{-1}$ as a soil application + zinc sulphate $\left(\mathrm{M}_{2} \mathrm{~S}_{5}\right)$ recorded the highest LAI of 6.9 and least LAI was recorded by the treatment wet seeded method + control (No manure) $\left(\mathrm{M}_{1} \mathrm{~S}_{1}\right)$.

INM increased leaf area index, as proper decomposition of organic matter supply available plant nutrient directly to plants and created favourable soil environment, ultimately increased nutrient supplying capacity of soil for long time, which resulted in better growth of the crop. The present findings are in line with observation made by kumar et al., (2010).

\section{Yield}

Among the main plot treatments, transplant method $\left(\mathrm{M}_{2}\right)$ showed a significant influence on grain and straw yield are given in table 4 . This might due to transplant method of planting of crops better utilized space, light, nutrients and air.
These reflects on higher grain and straw yield. Also the highest grain yield and straw yield was obtained by the effective utilization of resources which increased the performance of crop. This result is conformity with the reports of (Sarker et al., 2012).

With respect to subplot treatments, RDF + pressmud + Azospirillum bracilance@ $2 \mathrm{~kg} / \mathrm{ha}$ as a soil application + zinc sulphate $\left(\mathrm{S}_{5}\right)$ has significantly increased grain and straw yield.

The application of organic sources and fertility levels significantly affected the grain and straw yield of rice due to their positive influence on growth and yield attributes especially number of panicle hill ${ }^{-1}$, total number of grains panicle ${ }^{-1}$ and number of filled grains panicle ${ }^{-1}$. The increased in grain and straw yield of rice with combined application of inorganic, organic and biofertilizers sources of plant nutrient was attributed to significant improvement in growth and yield characters.

Table.1 Effect of planting methods and INM on Plant height of rice

\begin{tabular}{|c|c|c|c|c|c|c|}
\hline \multirow{2}{*}{ Treatments } & \multicolumn{2}{|c|}{ Flowering stage (cm) } & Mean & \multicolumn{2}{|c|}{ Harvesting stage (cm) } & \multirow{2}{*}{ Mean } \\
\cline { 2 - 3 } & $\mathbf{M}_{\mathbf{1}}$ & $\mathbf{M}_{\mathbf{2}}$ & & $\mathbf{M}_{\mathbf{1}}$ & $\mathbf{M}_{\mathbf{2}}$ & \\
\hline $\mathbf{S}_{\mathbf{1}}$ & 65.8 & 63.0 & $\mathbf{6 4 . 4}$ & 71.2 & 74.0 & $\mathbf{7 2 . 6}$ \\
\hline $\mathbf{S}_{\mathbf{2}}$ & 71.5 & 68.7 & $\mathbf{7 0 . 1}$ & 76.7 & 79.4 & $\mathbf{7 8 . 0}$ \\
\hline $\mathbf{S}_{\mathbf{3}}$ & 85.1 & 79.8 & $\mathbf{8 2 . 5}$ & 87.6 & 92.9 & $\mathbf{9 0 . 3}$ \\
\hline $\mathbf{S}_{\mathbf{4}}$ & 77.0 & 74.3 & $\mathbf{7 5 . 7}$ & 82.1 & 84.9 & $\mathbf{8 3 . 5}$ \\
\hline $\mathbf{S}_{\mathbf{5}}$ & 87.6 & 82.3 & $\mathbf{8 4 . 9}$ & 90.2 & 95.5 & $\mathbf{9 2 . 8}$ \\
\hline Mean & $\mathbf{7 7 . 4}$ & $\mathbf{7 3 . 6}$ & & $\mathbf{8 1 . 6}$ & $\mathbf{8 5 . 3}$ & \\
\hline & $\mathbf{S . E d}$ & $\mathbf{C D}$ & & $\mathbf{S . E d}$ & $\mathbf{C D}$ \\
\hline Main & 1.5 & $\mathbf{3 . 2}$ & & 1.6 & $\mathbf{3 . 5}$ \\
\hline Sub & 2.1 & $\mathbf{4 . 5}$ & & 2.0 & $\mathbf{4 . 3}$ \\
\hline M at S & 1.2 & $\mathbf{2 . 6}$ & & 1.2 & $\mathbf{2 . 6}$ & \\
\hline S at M & 1.1 & $\mathbf{2 . 4}$ & & 1.0 & $\mathbf{2 . 3}$ & \\
\hline
\end{tabular}


Table.2 Effect of planting methods and INM on tiller number $\mathrm{m}^{-2}$ at tiller stage, and LAI at flowering stage of rice

\begin{tabular}{|c|c|c|c|c|c|c|}
\hline \multirow{2}{*}{ Е } & \multicolumn{2}{|c|}{$\begin{array}{l}\text { Tiller number } \mathbf{m}^{-2} \\
\text { at tiller stage }\end{array}$} & \multirow[t]{2}{*}{ Mean } & \multicolumn{2}{|c|}{$\begin{array}{l}\text { LAI of rice at } \\
\text { flowering stage }\end{array}$} & \multirow[t]{2}{*}{ Mean } \\
\hline & $\mathbf{M}_{1}$ & $\mathbf{M}_{2}$ & & $\mathbf{M}_{1}$ & $\mathbf{M}_{2}$ & \\
\hline $\mathbf{S}_{1}$ & 304 & 332 & 318 & 4.5 & 4.8 & 4.6 \\
\hline $\mathbf{S}_{2}$ & 360 & 389 & 374.5 & 5.1 & 5.4 & 5.3 \\
\hline $\mathbf{S}_{\mathbf{3}}$ & 472 & 516 & 494 & 6.4 & 6.8 & 6.6 \\
\hline $\mathbf{S}_{4}$ & 418 & 447 & 432.5 & 5.7 & 6.0 & 5.9 \\
\hline $\mathbf{S}_{5}$ & 486 & 532 & 509 & 6.5 & 6.9 & 6.7 \\
\hline \multirow[t]{2}{*}{ Mean } & 408 & 443.2 & & 5.6 & 6.0 & \\
\hline & S.Ed & CD & & S.Ed & CD & \\
\hline Main & 12.73 & 27 & & 0.1 & 0.3 & \\
\hline Sub & 16.50 & 35 & & 0.2 & 0.5 & \\
\hline$M$ at $S$ & 10.37 & 22 & & 0.1 & 0.2 & \\
\hline$S$ at $M$ & 8.49 & 18 & & 0.08 & 0.1 & \\
\hline
\end{tabular}

Table.3 Effect of planting methods and INM of rice at grain yield and straw yield $\left(\mathrm{Kg} \mathrm{ha}^{-1}\right)$

\begin{tabular}{|c|c|c|c|c|c|c|}
\hline \multirow{2}{*}{ Treatments } & \multicolumn{2}{|c|}{ Grain yield $\left(\mathbf{K g ~ h a}^{-\mathbf{1}}\right)$} & \multirow{2}{*}{ Mean } & \multicolumn{2}{|c|}{ Straw yield $\left(\mathbf{K g ~ h a}^{\mathbf{- 1}}\right)$} & \multirow{2}{*}{ Mean } \\
\cline { 2 - 3 } & $\mathbf{M}_{\mathbf{1}}$ & $\mathbf{M}_{\mathbf{2}}$ & & $\mathbf{M}_{\mathbf{1}}$ & $\mathbf{M}_{\mathbf{2}}$ & \\
\hline $\mathbf{S}_{\mathbf{1}}$ & 2235 & 2800 & $\mathbf{2 5 1 7 . 5}$ & 3017 & 3394 & $\mathbf{3 2 0 5 . 5}$ \\
\hline $\mathbf{S}_{\mathbf{2}}$ & 3458 & 3881 & $\mathbf{3 6 6 9 . 5}$ & 4311 & 4602 & $\mathbf{4 4 5 6 . 5}$ \\
\hline $\mathbf{S}_{\mathbf{3}}$ & 4796 & 5366 & $\mathbf{5 0 8 1}$ & 5429 & 5947 & $\mathbf{5 6 8 8}$ \\
\hline $\mathbf{S}_{\mathbf{4}}$ & 4106 & 4572 & $\mathbf{4 3 3 9}$ & 4873 & 5165 & $\mathbf{5 0 1 9}$ \\
\hline $\mathbf{S}_{\mathbf{5}}$ & 5002 & 5486 & $\mathbf{5 2 4 4}$ & 5672 & 6182 & $\mathbf{5 9 2 7}$ \\
\hline Mean & $\mathbf{3 9 1 9 . 4}$ & $\mathbf{4 4 2 1}$ & & $\mathbf{4 6 6 0 . 4}$ & $\mathbf{5 0 5 8}$ & \\
\hline & $\mathbf{S . E d}$ & $\mathbf{C D}$ & & $\mathbf{S . E d}$ & $\mathbf{C D}$ & \\
\hline Main & 213.6 & $\mathbf{4 5 3}$ & & 180.1 & $\mathbf{3 8 2}$ & \\
\hline Sub & 249.5 & $\mathbf{5 2 9}$ & & 225 & $\mathbf{4 7 7}$ & \\
\hline M at S & 102.8 & $\mathbf{2 1 8}$ & & 121.6 & $\mathbf{2 5 8}$ \\
\hline S at $\mathbf{M}$ & 90.5 & $\mathbf{1 9 2}$ & & 100.4 & $\mathbf{2 1 3}$ \\
\hline
\end{tabular}

$\mathbf{M}_{1}$ - wet seeded method

$\mathbf{M}_{2}$-Transplanting method

$\mathbf{S}_{1^{-}}$Control (No manure)

$\mathbf{S}_{2}$-Recommended dose of fertilizer (120:38:38 N, P and $\left.\mathrm{K} \mathrm{kg} \mathrm{ha}^{-1}\right)$

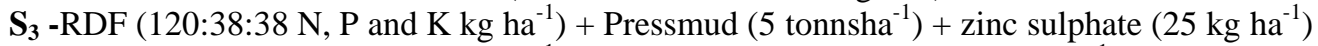

$\mathbf{S}_{4}-\operatorname{RDF}\left(120: 38: 38 \mathrm{~N}, \mathrm{P}\right.$ and $\left.\mathrm{K} \mathrm{kg} \mathrm{ha}^{-1}\right)+$ Azospirillum bracilance @ $2 \mathrm{~kg} \mathrm{ha}^{-1}$ as a soil application + zinc sulphate $(25$ $\left.\mathrm{kg} \mathrm{ha}^{-1}\right)$

$\mathbf{S}_{5}-\operatorname{RDF}\left(120: 38: 38 \mathrm{~N}, \mathrm{P}\right.$ and $\left.\mathrm{K} \mathrm{kg} \mathrm{ha}^{-1}\right)+$ pressmud $\left(5\right.$ tonnsha $\left.^{-1}\right)+$ Azospirillum bracilance@ $2 \mathrm{~kg} \mathrm{ha}^{-1}$ as a soil application + zinc sulphate $\left(25 \mathrm{~kg} \mathrm{ha}^{-1}\right)$ 
Table.4 Effect of planting methods and INM of rice at economics of various treatments

\begin{tabular}{|c|c|c|c|c|c|c|}
\hline Treatments & $\begin{array}{l}\text { Grain yield } \\
\quad\left(\mathrm{kg} \mathrm{ha}^{-1}\right)\end{array}$ & $\begin{array}{l}\text { Straw yield } \\
\left(\mathrm{kg} \mathrm{ha}^{-1}\right)\end{array}$ & $\begin{array}{c}\text { Cost of } \\
\text { cultivation } \\
\left(\text { ha }^{-1}\right)\end{array}$ & $\begin{array}{c}\text { Gross return } \\
\left(\text { ha }^{-1}\right)\end{array}$ & $\begin{array}{l}\text { Net return } \\
\left(\text { ha }^{-1}\right)\end{array}$ & B:C Ratio \\
\hline $\mathbf{M}_{1} \mathbf{S}_{1}$ & 2235 & 3017 & 20780.00 & 37268.50 & 16488.50 & 1.79 \\
\hline $\mathbf{M}_{1} \mathbf{S}_{3}$ & 4796 & 5429 & 32645.00 & 79450.50 & 46805.50 & 2.43 \\
\hline $\mathbf{M}_{1} \mathbf{S}_{4}$ & 4106 & 4873 & 27695.00 & 68132.50 & 40437.50 & 2.46 \\
\hline $\mathbf{M}_{1} \mathbf{S}_{5}$ & 5002 & 5672 & 32695.00 & 82868.00 & 50173.00 & 2.53 \\
\hline $\mathbf{M}_{2} \mathbf{S}_{2}$ & 3881 & 4602 & 29645.00 & 64397.00 & 34752.00 & 2.17 \\
\hline $\mathbf{M}_{2} \mathbf{S}_{3}$ & 5366 & 5947 & 35645.00 & 88829.50 & 53184.50 & 2.49 \\
\hline $\mathbf{M}_{2} \mathbf{S}_{4}$ & 4572 & 5165 & 30695.00 & 75734.50 & 45039.50 & 2.47 \\
\hline $\mathbf{M}_{2} \mathbf{S}_{5}$ & 5486 & 6182 & 35695.00 & 90867.00 & 55172.00 & 2.55 \\
\hline
\end{tabular}


The efficient supply of nutrient delayed the senescence and increased the life cycle of the plant, which resulted in higher economic yield.

Judicious use of organic and inorganic fertilizer enabled rice plant to assimilate sufficient photosynthates resulting in increased dry matter production and these together produced more productive tillers, panicle and number of filled grains leading to higher grain yield Hossaen et al., (2011).

Among the various treatment combinations, transplant method and $\mathrm{RDF}+$ pressmud + Azospirillum bracilance@ $2 \mathrm{~kg} / \mathrm{ha}$ as a soil application + zinc sulphate $\left(\mathrm{M}_{2} \mathrm{~S}_{5}\right)$ exerted significant result on grain yield of crop, over other treatments combinations the better establishment of crops in transplant method resulted in favourable physical, chemical and biological condition of soil along with balanced application of nutrient by $\mathrm{RDF}+$ pressmud+Azospirillum bracilance@ $2 \mathrm{~kg} / \mathrm{ha}$ as a soil application + zinc sulphate which efficiently increased the grain yield compared to other treatment combinations. The recorded higher straw yield due to higher LAI and dry matter production.

\section{Grain yield}

The data on grain yield showed significant variance among main and sub treatments are presented in Table 3.

Among the main treatments, transplanting method $\left(\mathrm{M}_{2}\right)$ gave the highest mean yield of $4421 \mathrm{~kg} \mathrm{ha}^{-1}$ after that followed by wet seeded rice method $\left(\mathrm{M}_{1)}\right.$ with a yield of $3919.4 \mathrm{~kg}^{-}$ 1 . The treatments were significantly different from each other.

Among various sub treatments, $i$.e., certain levels and sources of nutrients, RDF + pressmud + Azospirillum bracilance@ 2 kg $\mathrm{ha}^{-1}$ as a soil application + zinc sulphate $\left(\mathrm{S}_{5}\right)$ recorded the highest grain yield of $5244 \mathrm{~kg}$ $\mathrm{ha}^{-1}$ which was on par with RDF + Pressmud + zinc sulphate $\left(\mathrm{S}_{3}\right)$ with $5081 \mathrm{~kg} \mathrm{ha}^{-1}$ The smallest grain yield was obtained with no fertilizer plot $\left(\mathrm{S}_{1}\right)$, the yield being $2517.5 \mathrm{~kg}$ $\mathrm{ha}^{-1}$.

There was significant interaction between the planting methods and application of different nutrients on rice for grain yield. The treatment combination of transplanting method $+\mathrm{RDF}+$ pressmud + Azospirillum bracilance@ $2 \mathrm{~kg}$ $\mathrm{ha}^{-1}$ as a soil application + zinc sulphate $\left(\mathrm{M}_{2} \mathrm{~S}_{5}\right)$ recorded the highest grain yield of $5486 \mathrm{~kg} \mathrm{ha}^{-1}$ and least grain yield was recorded by the treatment wet seeded method + control (No manure) $\left(\mathrm{M}_{1} \mathrm{~S}_{1}\right)$.

\section{Straw yield}

The data on straw yield exhibited significant alteration among main as well as sub treatments are presented in Table 3.

Among the main treatment, transplanting method $\left(\mathrm{M}_{2}\right)$ gave the peak straw yield of $5058 \mathrm{~kg} \mathrm{ha}^{-1}$ and followed by wet seeded rice method with a straw yield of $4660.4 \mathrm{~kg} \mathrm{ha}^{-1}$. The treatments were expressively different from each other.

Among various sub treatments, i.e., certain levels and sources of nutrients, RDF + pressmud + Azospirillum bracilance@ 2 kg $\mathrm{ha}^{-1}$ as a soil application + zinc sulphate $\left(\mathrm{S}_{5}\right)$ recorded the largest straw yield of $5927 \mathrm{~kg} \mathrm{ha}^{-}$ ${ }^{1}$ which was on par with RDF + Pressmud + zinc sulphate $\left(\mathrm{S}_{3}\right)$ with $5688 \mathrm{~kg} \mathrm{ha}^{-1}$. The smallest straw yield was obtained with no fertilizer plot $\left(\mathrm{S}_{1}\right)$, the yield being $3205.5 \mathrm{~kg}$ $\mathrm{ha}^{-1}$. There was significant interaction between the planting methods and application of different nutrients on rice for straw yield. The treatment combination of transplanting method $+\mathrm{RDF}+$ pressmud + Azospirillum 
bracilance@ $2 \mathrm{~kg} \mathrm{ha}^{-1}$ as a soil application + zinc sulphate $\left(\mathrm{M}_{2} \mathrm{~S}_{5}\right)$ recorded the highest straw yield of $6182 \mathrm{~kg} \mathrm{ha}^{-1}$ and least straw yield was recorded by the treatment wet seeded method + control (No manure) $\left(\mathrm{M}_{1} \mathrm{~S}_{1}\right)$.

\section{Economics}

The data on cost of cultivation, gross returns, net return and befit cost ratio are presented in Table 4.

Between different methods of planting and different levels and sources of nutrients, the gross return and net return varied to a considerable extent. Higher gross return (Rs. 90867) and net return (Rs. 55172) and B:C ratio (Rs. 2.55) were realized in the rice crop raised from transplanting method with the application of $\mathrm{RDF}+$ pressmud + Azospirillum bracilance@ $2 \mathrm{~kg} \mathrm{ha}^{-1}$ as a soil application + zinc sulphate $\left(\mathrm{M}_{2} \mathrm{~S}_{5}\right)$.

Next promising treatment combination is transplanting method with the application of $\mathrm{RDF}+$ pressmud + Azospirillum bracilance@ $2 \mathrm{~kg} \mathrm{ha}^{-1}$ as a soil application + zinc sulphate $\left(\mathrm{M}_{1} \mathrm{~S}_{5}\right)$ which gave the gross return (Rs. 82868) and net return (Rs. 50173) and B:C ratio (Rs. 2.53). The lower gross return (Rs. 37268.50) and net return (Rs. 16488.50) and $\mathrm{B}: \mathrm{C}$ ratio (Rs. 1.79) was obtained wet seeded method with no fertilizer plot $\left(\mathrm{M}_{1} \mathrm{~S}_{1}\right)$.

Transplanting method of rice cultivation showed the maximum performance when combined with RDF + pressmud + Azospirillum bracilance@ $2 \mathrm{~kg} \mathrm{ha}^{-1}$ as a soil application + zinc sulphate returned the maximum growth parameter its leads to increase the yield of the rice crop.Hence, the above treatment can be suggested to the rice farmers to augment the rice productivity with sizeable economic gains and without any significant loss on soil health.

\section{References}

Chaudhary, S. K., Thakur, S. K., and Pandey, A. $\mathrm{K}$. Response of wetland rice to nitrogen and zinc. Indian J. Agron., 2007; 44(1), 31-34.

Ehsanullah, Ijaz Iqbal, Ashfaq Ahmad and Shakeel Ahmad Randhawa. Effect of Direct Seeding and Transplanting Methods on the Yield and Quality of fine Rice Basmati-370. International journal of agricultural \& biology. 2000; $251-252$.

Fageria, N. K., V.C. Baligar, and R. B. Clark. Micronutrients in crop production. Advances in Agronomy 2002; 77: 185 -268 .

FAO. Food Security and Agricultural Mitigation in Developing Countries: Options for Capturing Synergies. 2009.

Farooq, M., Siddique KHM, Rehman H, Aziz T, Dong- Jin Lee and Wahid. Rice direct seedling: Experience, challanges and opportunities. Soil Tillage Res. 2011; 111: 87-98.

Goud, V.V., and N.M. Konde. Influence of conjective use of farmyard manure and inorganic fertilizers on yield, nutrient uptake, economics and soil fertility in rice-mustard sequence. Crop Sci., Green Farming. 2009; 2(2):1005 - 1007.

Hatwar, G.P., S.U. Gondane, S.M. Urkude and O.V. Gahukar. Effect of micronutrients on growth and yield of chilli. J. Soils Crops. 2003; 13: 123- 125.

Hossaen, M.A., A.T. Shamsuddoha, A.K. Paul, M.S.I. Bhuiyan and A.S.M. Zobaer. Efficiency of different organic manures and inorganic fertilizer on the yield and yield attributes of boro rice. The Agric., 2011; 9(1\&2): 117 - 125.

Jagdish Kumar, M., P. Yadav and Kedar Prasad. Production potential of hybrid rice (Oryza sativa L.) as influenced by integrated nutrient management. Crop Res., 2010; 39 (1,2\&3): 2023.1 
Kirkby, E.A. and V. Romheld. Micronutrients in plant Physiology: Functions Uptake and mobility. Proceeding No. 543. International Fertilizers Society, York, UK. 2004; 1-51.

Kumar, N., K.K. Chandra and R. Singh. Integrated plant nutrient supply system on growth, yield and economics of rice. Indian J. Fertil., 2010; 6 (2): 25-28.

Mankotia, B.S., J. Shekhar., R.C. Thakur and S.C. Negi. Effect of organic and inorganic sources of nutrients on rice.
Ind. J. Agron., 2008; 53 (1): 32 - 36.

Sarkar, A, Islam, T, Biswas, G.C., Alam, M.S., Hossain, M. Screening for phosphate solubilising bacteria inhabiting the rhizoplane of rice rice grown in acidic soil in Bangladesh. Indian J. Agron., 2012; 23, 645-651.

Zhao L, Wu L, Wu M, Li Y. Nutrient uptake and water use efficiency as affected by modified rice cultivation methods with irrigation. Paddy Water Environ. 2011; 9:25-32.

\section{How to cite this article:}

Mohanasundar, C., M. Saravana Perumal and Murugan, G. 2021. Effect of Economic Evaluation of Oryza sativa under different Planting Methods and Nutrient Management Practices. Int.J.Curr.Microbiol.App.Sci. 10(02): 1614-1624.

doi: https://doi.org/10.20546/ijcmas.2021.1002.192 